Annals of the

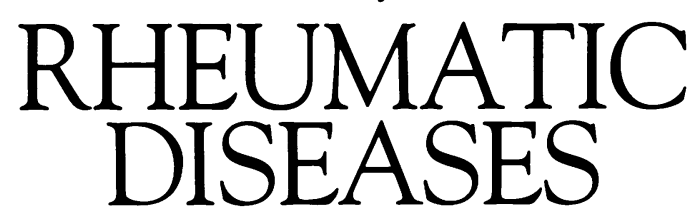

Leader

\title{
Rheumatoid nodules: differential diagnosis and immunohistological findings
}

The presence of nodules in para-articular subcutaneous tissue in patients with peripheral rheumatoid arthritis (RA) is commonly regarded as an extra-articular manifestation of rheumatoid disease. Generally in these cases the presence of chronic inflammatory subcutaneous nodules does not create diagnostic problems for the clinician. Occurring in 20 to $30 \%$ of white patients with definite RA, ${ }^{1}$ nodules are found most commonly on extensor surfaces at sites of frequent mechanical irritation ${ }^{2}$ : proximal ulna, on the olecranon process (where they must be differentiated from a bursitis olecrani with enlargement of the synovial layer), extensor tendons of the hand (at the level of the metacarpophalangeal or the proximal interphalangeal joint), the back of the head and ears, the back of the heels, and the ischial tuberosities. When mechanical irritation is suppressed the nodules may disappear within a few days. Nodules vary in consistency from firm immovable masses when they are small to soft mobile masses when they are large. Nodules may also develop in tendons or in visceral organs. They may ulcerate or may become gangrenous. Rheumatoid factor is almost always found at a high titre in the serum of patients with rheumatoid nodules. ${ }^{3}$ The presence of subcutaneous nodules in a patient with an active inflammatory joint disease in the absence of rheumatoid factor makes the diagnosis of RA extremely improbable and it is necessary to look for other connective tissue and vasculitic diseases rather than $R A$.

Generally there is a discrepancy between the presence of extensive extra-articular manifestations (subcutaneous nodules, necrotising vasculitis, etc...) and the inflammatory state of the joints. Explosive manifestation of extra-articular activity is often accompanied by regression of the joint inflammation. The reverse of this phenomenon was recently reported in patients with RA treated with methotrexate: the patients whose joint symptoms were improving owing to administration of this drug often developed more and larger subcutaneous nodules. ${ }^{4-6}$

Further diagnostic problems occur for the clinician in patients with subcutaneous nodules but without RA. Differential diagnosis must be performed with rheumatoid nodulosis, benign rheumatoid nodules, the subcutaneous type of granuloma annulare, and subcutaneous nodules associated with rheumatic fever ${ }^{7}$ (table).

Multiple subcutaneous nodules in the presence of rheumatoid factors and in the absence of any joint complaints suggest firmly a diagnosis of rheumatoid nodulosis. ${ }^{89}$ In this case nodules are mostly numerous, small, and concentrated in hands and feet but not limited on the extensor side of fingers and toes. Occasionally, the rheumatoid nodulosis may extend to complete rheumatoid disease, in which the joints are affected; this evolution may be seen 20 or 30 years after appearance of the nodulosis.

Benign rheumatoid nodules are usually found in healthy children without clinical or serological signs of an associated rheumatological or other disease. ${ }^{10} 11$ These nodules are histologically indistinguishable from those occurring in RA; they are non-tender and often appear on the pretibial regions, feet, and scalp. They increase rapidly in size and resolve spontaneously. Appearance of benign rheumatoid nodules for the first time after the age of 18 is unusual. The same lesions may be located more superficially, appearing usually as intracutaneous nodules

Differential diagnosis in patients with subcutaneous nodules

\begin{tabular}{|c|c|c|c|c|c|}
\hline Features & $\begin{array}{l}R A \text { associated rheumatoid } \\
\text { nodules }\end{array}$ & Rheumatoid nodulosis & Rheumatic fever nodules & Benign rheumatoid nodules & Granuloma annulare \\
\hline Localisation & Extensor sites & $\begin{array}{l}\text { Extensor sites or any other } \\
\text { site }\end{array}$ & $\begin{array}{l}\text { Extensor sites, also over } \\
\text { the processus spinosi } \\
\text { of vertebrae }\end{array}$ & $\begin{array}{l}\text { Extensor sites, pretibial, } \\
\text { feet, scalp }\end{array}$ & Extensor site or any other site \\
\hline Depth & Subcutaneous & Subcutaneous & Subcutaneous & Subcutaneous & Intradermal (subcutaneous) \\
\hline Pathology & $\begin{array}{l}\text { Central necrosis, palisading } \\
\text { mononuclear cells, } \\
\text { perivascular lymphocytic } \\
\text { infiltrations }\end{array}$ & $\begin{array}{l}\text { Central necrosis, palisading } \\
\text { mononuclear cells, } \\
\text { perivascular lymphocytic } \\
\text { infiltration }\end{array}$ & $\begin{array}{l}\text { Central necrosis, little } \\
\text { histiocytic/lymphocytic } \\
\text { infiltration }\end{array}$ & $\begin{array}{l}\text { Central necrosis, palisading } \\
\text { mononuclear cells, } \\
\text { perivascular lymphocytic } \\
\text { infiltrates }\end{array}$ & $\begin{array}{l}\text { Central necrosis, palisading } \\
\text { histiocytes }\end{array}$ \\
\hline Age of onset & Adult & Adult & Children & Children & Children, young adults \\
\hline Persistence & Chronic & Chronic & Limited & Limited & Unpredictable \\
\hline Rheumatoid factor & Present & Present & Absent & Absent & Absent \\
\hline $\begin{array}{l}\text { Concomitant joint } \\
\text { disease }\end{array}$ & Yes & $\begin{array}{l}\text { None (may precede } \\
\text { polyarthritis) }\end{array}$ & Yes & None & None \\
\hline Bone erosions & Present & Sometimes present & Absent & Absent & Absent \\
\hline
\end{tabular}


but with identical histological characteristics, and these are called granuloma annulare.

Subcutaneous small nodules, no larger than peas, are found in acute rheumatic fever. ${ }^{7}$ Concomitant clinical findings are required for differentiation.

The pathogenic mechanism leading to the formation of rheumatoid nodules associated with $\mathrm{RA}$ remains unclear. Recent studies of immune cells present in these lesions have produced new insights. Histologically, a rheumatoid nodule is composed of three zones: an inner zone of central necrosis, a surrounding cellular palisading zone, and an outer area with perivascular infiltration of chronic inflammatory cells. ${ }^{2}$ The major proportion of the palisaded cells are macrophages, which stain positive with macrophage specific antibodies and are HLA-DR positive. $T$ lymphocytes are found in variable numbers distributed among the macrophages and, more importantly, in the area surrounding the palisaded mononuclear cells, where they are concentrated around small vessels. These lymphocytes are mainly CD3 positive T lymphocytes. ${ }^{12}$ Only a minority of these infiltrating lymphocytes seem to be activated, as indicated by the low expression of interleukin-2 (IL-2) receptor (expressed by $1 \%$ or less of infiltrating $T$ lymphocytes). ${ }^{12} 13$ The role of $T$ lymphocytes in the pathogenesis of rheumatoid arthritis is still debated but generally accepted..$^{14-16}$ An important question arises as to the role of antigen specific $T$ cells in the development of rheumatoid nodules. To examine this role, additional immunological analysis of $\mathrm{T}$ lymphocytes present in rheumatoid nodules has been carried out in our laboratory. 12 Immunohistochemical staining of infiltrating lymphocytes with $\mathrm{T}$ cell receptor specific monoclonal anti-idiotypic antibodies showed a polyclonal $\mathrm{T}$ cell population with $\mathrm{V} \beta$ representation comparable with that in peripheral blood lymphocytes. The low expression of IL-2 receptor among lymphocytes in situ was confirmed. To analyse further the activated IL-2 receptor positive lymphocytes these cells were expanded in vitro by stimulation with IL-2. The clonality of these IL-2 expanded $T$ cells was analysed with antibodies to $T$ cell receptor by flow cytometry. It was found that IL-2 responsive $\mathrm{T}$ lymphocytes were strikingly oligoclonal, as reflected by marked overrepresentation of one specific idiotype in each expanded cell line. This idiotype differed from patient to patient. In one patient, however, in whom two nodules were present with a time interval of six months, the same idiotype predominantly expanded under IL-2 stimulation.

These data suggest that a specific $\mathrm{T}$ cell mediated immune reaction occurs in rheumatoid nodules. The precise relation between immune reactions occurring in rheumatoid nodules, on the one hand, and in rheumatoid synovium, on the other, remains unresolved.

Afdeling Reumatologie,

E M VEYS

Universitair Ziekenhuis, F DE KEYSER

De Pintelaan 185,

B-9000 Gent,

Belgium.

1 Kaye B R, Kaye R L, Bobrove A. Rheumatoid nodules. Review of the spectrum of associated conditions and proposal of a new classification, with a report of four seronegative cases. $A m \Im M$ Med 1984; 76: 279-92.

2 With a report of four seronegative cases. Am f Med 1984; 76: 279

3 Miyasaka N, Sato K, Yamamoto K, Goto M, Nishioka K. Immunological and immunohistochemical analysis of rheumatoid nodules. Ann Rheum Dis 1989; 48: 220-6.

4 Furst D E, Kremer J M. Methotrexate in rheumatoid arthritis. Arthritis Rheum 1988; 31: 305-14.

5 Segal R, Caspi D, Tishler M, Fiskel B, Yaron M. Accelerated nodulosis and vasculitis during methotrexate therapy for rheumatoid arthritis. Arthritis Rheum 1988; 31: 1182-5.

6 Fuchs $\mathrm{H}$ A. Rheumatoid vasculitis with worsening nodulosis. $f$ Rheumatol $1990 ; 17: 123-4$.

7 Wood M G, Beerman H. Necrobiosis lipoidica, granuloma annulare and rheumatoid nodule. $\mathcal{F}$ Invest Dermatol 1960; 34: 139-47.

8 Bywaters E G. A variant of rheumatoid arthritis characterized by recurrent digital pad nodules and palmar fasciitis, closely resembling palindromic rheumatism. Ann Rheum Dis 1949; 8: 2-30.

9 Ginsberg M H, Genant H K, T'Sifan Y, McCarty D J. Rheumatoid nodulosis: an unusual variant of rheumatoid disease. Arthritis Rheum 1975; 18: 49-58.

10 Burry H C, Caughey D E, Palmer D G. Benign rheumatoid nodules. Aust NZ F Med 1979; 9: 697-701.

11 Cohen $P$ R, Kurzrock R. Benign rheumatoid nodules in a woman with chronic lymphocytic leukaemia and borderline lepromatous leprosy. Ann Rheum Dis 1993; 52: 685-8.

12 De Keyser F, Verbruggen G, Veys E M, et al. T-cell receptor Vbeta usage in rheumatoid nodules: marked oligoclonality among IL-2 expanded lymphocytes. Clin Immunol Immunopathol. In press.

13 Highton J, Palmer D G, Smith M, Hessian P A. Phenotypic markers of lymphocyte and mononuclear phagocyte activation within rheumatoid nodules. F Rheumatol 1990; 17: 1130-6.

14 Klareskog L, Rönnelid J, Gudmundsson S, Karlsson-Parra A. Rheumatoid arthritis. Curr Opin Rheumatol 1991; 3: 912-6.

15 Holoshitz J, Naperstek Y, Ben-Nun A, Cohen I R. Lines of T lymphocyte induce or vaccinate against autoimmune arthritis. Science 1983; 219: $56-8$.

16 Cohen I R, Holoshitz J, Van Eden W, Frenkel A. T lymphocyte clones illuminate pathogenesis and effect therapy of experimental arthritis. Arthritis Rheum 1985; 28: 841-5.

17 De Keyser F, Verbruggen G, Veys E M. T cell receptor expression in patients with rheumatic diseases. Progr Histochem Cytochem 1993; 26: $218-22$. 